\title{
Wheat storage proteins: changes on the glutenins after wheat infection with different isolates of Fusarium graminearum
}

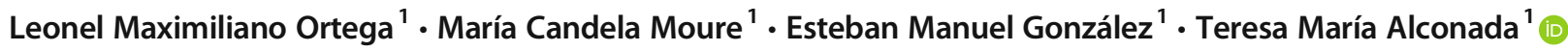

Received: 4 July 2018 / Revised: 14 November 2018 / Accepted: 26 November 2018 / Published online: 7 December 2018

(C) Springer Nature Switzerland AG 2018

\begin{abstract}
Wheat gluten proteins are decisive for the industrial properties of flour, so alterations resulting from grain infection with Fusarium graminearum produce changes in the glutenin content that affect the baking properties. This work analyzes the high-molecular-weight glutenin changes from wheat flour with different degrees of $F$. graminearum infection at field, since these proteins are determinant for the quality properties of flour. Wheat cultivars—on field trials - infected with $F$. graminearum isolates of diverse aggressiveness showed severity values between 9.1 and $42.58 \%$ and thousand kernel weight values between 28.12 and $32.33 \mathrm{~g}$. Negative correlations between severity and protein content and positive correlations between yield and protein content were observed, employing reversed-phase high-performance liquid chromatography and polyacrylamide gel electrophoresis. Furthermore, the protein signal changes were in agreement for both methodological approaches. Also, the degree of disease observed and the protein changes on infected wheat cultivars varied in relation with the aggressiveness of the isolate responsible for the infection. The principal component analysis showed a close arrangement among protein values obtained by HPLC. For each cultivar, two principal components were obtained, which explained $80.85 \%, 88.48 \%$, and $93.33 \%$ of the total variance (cultivars Sy200, AGP Fast, and Klein Tigre respectively). To our knowledge, the approaches employed for the analysis of protein changes according to the degree of disease, as well as the thorough statistical analysis, are novel for the study of Fusarium Head Blight.
\end{abstract}

Keywords Whole grain flour · Aggressiveness $\cdot$ Fungal infection $\cdot$ Gluten proteins $\cdot$ HPLC analysis $\cdot$ SDS-PAGE analysis

\section{Introduction}

Wheat (Triticum aestivum) is one of the most extended crops around the world, along with corn and rice. Nowadays, the principal exporters are the USA, Canada, the European Union, Argentina, and Australia (FAO 2015). Wheat flour-main derivate of graincomes from the endosperm, which is the most abundant structural component of the grain. The endosperm is mainly composed of starch and storage proteins, which function as an energy reservoir during germination

Teresa María Alconada

alconada@biotec.quimica.unlp.edu.ar

1 Centro de Investigación y Desarrollo en Fermentaciones Industriales (CINDEFI), UNLP, CCT-La Plata, CONICET, Facultad de Ciencias Exactas, Universidad Nacional de La Plata, Calle 47 y 115, B1900ASH La Plata, Argentina
(DuPont and Altenbach 2003; Gianibelli et al. 2001; Gras et al. 2001; Shewry et al. 2013). The protein content determines the market value, industrial quality, and end use of the grains and flours, since it forms the viscoelastic net necessary to retain the gas during the fermentation process (Wieser 2007). Gluten is composed of gliadins and glutenins (DuPont and Altenbach 2003; Gianibelli et al. 2001; Gras et al. 2001). Both types of proteins have different effects on dough; while monomeric gliadins determine viscosity and extensibility, glutenins' capacity to form disulfure bonds is responsible for the elasticity and cohesiveness of the dough (Belton 2005; Kamal et al. 2009; Payne et al. 1987). The glutenins are classified into low- and high-molecular-weight glutenin subunits (LMW-GS and HMW-GS respectively) (Belton 2005; D'Ovidio and Masci 2004). HMW-GS proteins are encoded by three genes (GluA1, GluB1, and GluD1) that constitute the Glu-1 gene group. Each gene presents different alleles that code for different proteins, which have a differential influence on the quality of wheat, so alterations 
Table 1 Cultivars employed in field assay

\begin{tabular}{lll}
\hline Cultivar & Resistance & Growth cycle \\
\hline Sy 200 & Susceptible & Medium \\
AGP Fast & Moderately susceptible & Short \\
Klein Tigre & Moderately resistant & Short \\
Sumai 3 & Totally resistant & Medium \\
\hline
\end{tabular}

in the HMW-GS protein fraction can reduce the quality of the flour (Payne et al. 1987).

Wheat is susceptible to various diseases, Fusarium Head Blight (FHB) being one of the most devastating diseases worldwide, since it produces high economic losses due to yield and quality reduction (Kikot et al. 2011; McMullen et al. 1997; Monds et al. 2005), and the associated presence of mycotoxins in the infected grains (Palacios et al. 2011). The FHB disease is mainly caused by members of the Fusarium genus, Fusarium graminearum sensu stricto (s.s.) being the principal etiological agent in wet and temperate geographic regions (Alvarez et al. 2011; Castañares et al. 2014; Ortega et al. 2016). When the wheat plant is on the phenological state of anthesis, the pathogen can penetrate and infect the exposed tissues (Pritsch et al. 2000). Once the colonization has initialized, the fungal hypha produces enzymes that degrade the structural components of the cell walls, allowing the spread of the disease through the spikes (Kang et al. 2005; Kang and Buchenauer 2000; Kikot et al. 2009; Mesterházy et al. 1999; Wanjiru et al. 2002). On the late infection stage, the protease enzymes released can degrade the gluten, causing a reduction in the quality and industrial properties of the derived flours (Barneix 2007; Brzozowski et al. 2008). The pathogen capacity to release these enzymes can determine the aggressiveness of each isolate. The high intraspecific diversity (Akinsanmi et al. 2008; Tóth et al. 2005) generates variability in the aggressiveness of the isolates, and as a consequence it induces different degrees of infection (Malbrán et al. 2012).
In wheat breeding programs, where the size of the sample is limiting, the electrophoresis and chromatography are among the most suitable techniques of analysis (Eggert et al. 2010 ). Due to the high resolution of reversed-phase and molecular exclusion high-performance liquid chromatography, both techniques are widely employed in the study of the composition of infected and uninfected wheat flours (Larroque et al. 2000; Naeem and Sapirstein 2007; Ueno et al. 2002)

To our knowledge, the majority of the researches related to Fusarium infection and wheat protein changes are only focused on the major components of gluten, the studies of single protein type being scarce (Horvat et al. 2014). The present research provides a novel approach to the relation between field infection and protein changes measured by analytical methods. Therefore, the aim of the present work was to analyze the changes on HMW-GS proteins of whole wheat flour from grains with different degrees of Fusarium graminearum s.s. infection, since these proteins are determinant for the quality properties of flours.

\section{Materials and methods}

\section{Biological Material}

Three wheat cultivars that belong to the national wheat breeding program of Marcos Juárez-INTA (Córdoba, Argentina) were employed in this study: Sy 200, AGP Fast, and Klein Tigre, selected according to their growth cycle and resistance to infection. The international highresistant cultivar Sumai 3 was employed as a control (Table 1). The wheat plants were sowed during winter 2013 in the experimental field of Marcos Juárez-INTA $\left(32^{\circ} 42^{\prime} \mathrm{S} ; 62^{\circ} 06^{\prime} \mathrm{W}\right)$ under conditions similar to those in the field, but with partial control of humidity using a field microsprinkler, as in previous works (Alberione et al. 2016).

The infection was carried out with three Fusarium graminearum sensu stricto isolates with different degrees
Table 2 Aggressiveness characterization of Fusarium graminearum isolates

\begin{tabular}{|c|c|c|c|c|}
\hline \multirow[t]{2}{*}{ Isolate } & \multicolumn{2}{|c|}{ Enzymatic activity } & \multirow[t]{2}{*}{ Toxicologic capacity } & \multirow[t]{2}{*}{ Isolate aggressiveness } \\
\hline & PG & Protease & & \\
\hline 1 & ++ & + & +++ & Low \\
\hline 2 & ++ & +++ & + & Medium \\
\hline 3 & ++++ & +++ & +++ & High \\
\hline
\end{tabular}

$P G$, polygalacturonase; + , relative enzymatic and toxicologic productions 
Fig. 1 Severity and thousand kernel weight of wheat field treatments. TKW, thousand kernel weight. The same letter means no significant differences, obtained by ANOVA
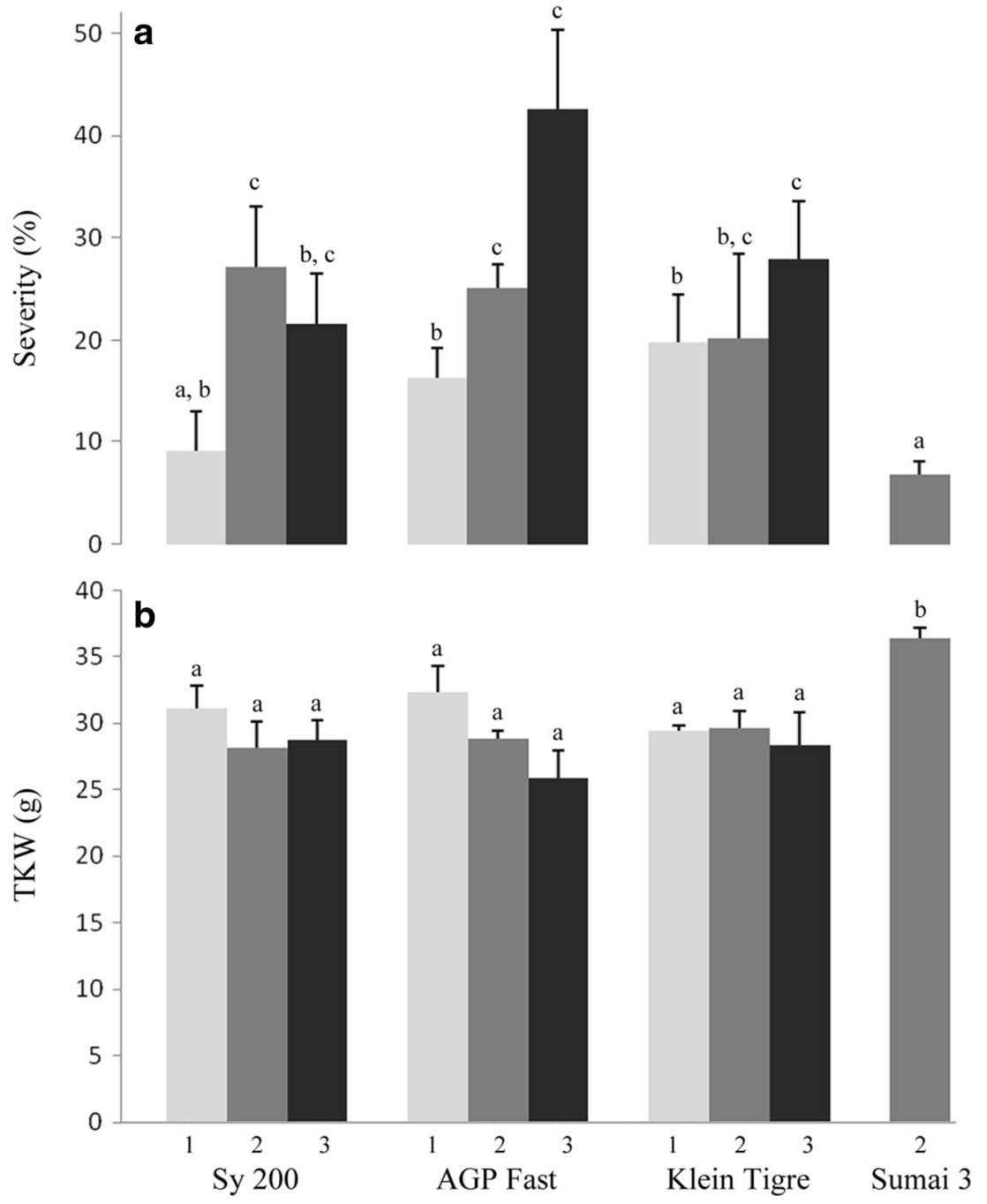

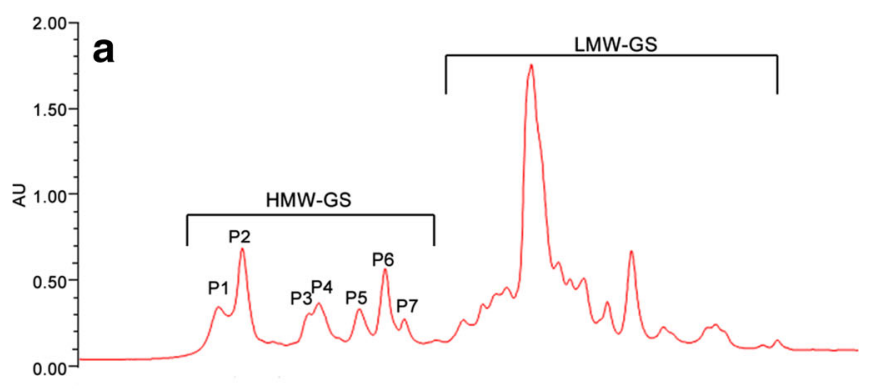

b

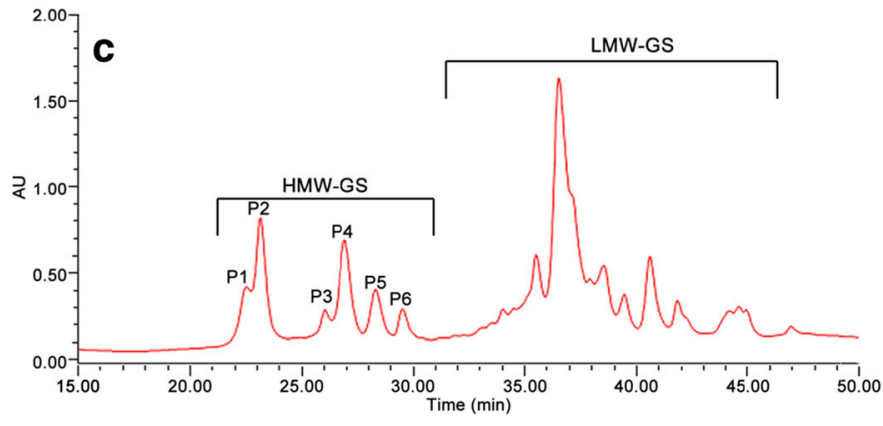

Fig. 2 Representative elution profiles of glutenin extracts obtained from Sy 200 (a), AGP Fast (b), and Klein Tigre (c) cultivars, and Sumai 3 control cultivar (d) infected with isolate 2 on RP-HPLC chromatography.
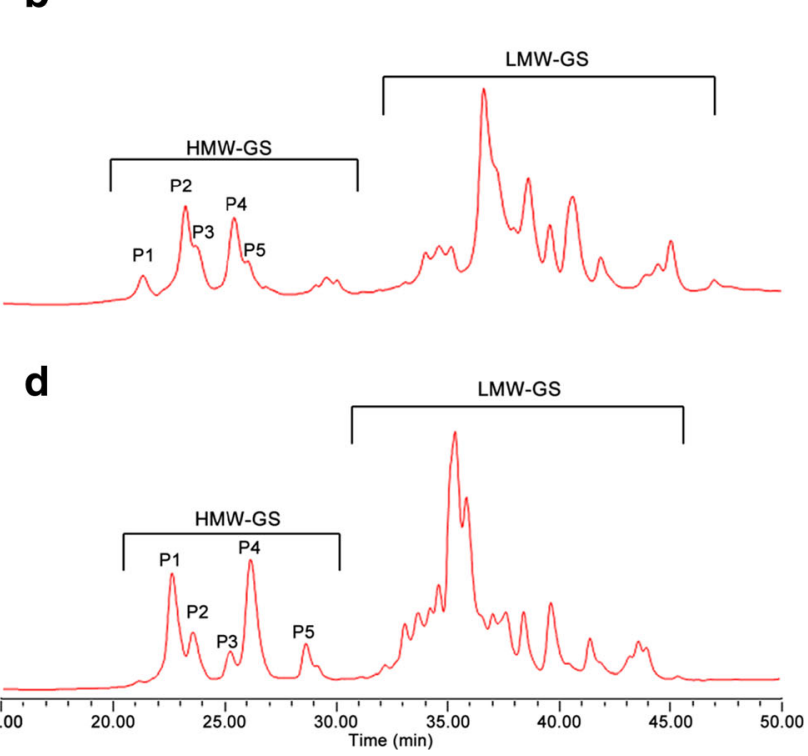

HMW-GS, high-molecular-weight glutenin subunit; LMW-GS, lowmolecular-weight glutenin subunit; P1-P7, proteic peaks; AU, absorbance units at $206 \mathrm{~nm}$ 
Table 3 Pearson's correlation matrix from RP-HPLC areas under the peaks for wheat cultivars

\begin{tabular}{|c|c|c|c|c|c|c|c|c|}
\hline \multirow{8}{*}{ 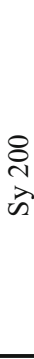 } & & P1 & $\mathrm{P} 2$ & P3 & $\mathrm{P} 4$ & P5 & P6 & P7 \\
\hline & $\mathrm{P} 1$ & 1.00 & & & & & & \\
\hline & $\mathrm{P} 2$ & $0.97 *$ & 1.00 & & & & & \\
\hline & P3 & $0.92 *$ & $0.90 *$ & 1.00 & & & & \\
\hline & P4 & $0.91 *$ & $0.96^{*}$ & $0.83 *$ & 1.00 & & & \\
\hline & P5 & 0.80 & 0.78 & 0.68 & $0.90^{*}$ & 1.00 & & \\
\hline & P6 & $0.92 *$ & $0.95 *$ & $0.85^{*}$ & $1.00 *$ & $0.91 *$ & 1.00 & \\
\hline & P7 & 0.17 & 0.22 & -0.10 & 0.30 & 0.36 & 0.25 & 1.00 \\
\hline \multirow{6}{*}{ 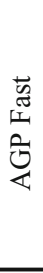 } & & $\mathrm{P} 1$ & $\mathrm{P} 2$ & P3 & P4 & P5 & & \\
\hline & $\mathrm{P} 1$ & 1.00 & & & & & & \\
\hline & $\mathrm{P} 2$ & $0.82 *$ & 1.00 & & & & & \\
\hline & P3 & $0.82 *$ & $0.97 *$ & 1.00 & & & & \\
\hline & P4 & $0.89 *$ & $0.98 *$ & $0.96^{*}$ & 1.00 & & & \\
\hline & P5 & $0.81 *$ & $0.89 *$ & $0.92 *$ & $0.94 *$ & 1.00 & & \\
\hline \multirow{7}{*}{ 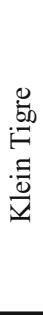 } & & $\mathrm{P} 1$ & P2 & P3 & $\mathrm{P} 4$ & P5 & P6 & \\
\hline & $\mathrm{P} 1$ & 1.00 & & & & & & \\
\hline & $\mathrm{P} 2$ & 0.76 & 1.00 & & & & & \\
\hline & $\mathrm{P} 3$ & -0.60 & -0.20 & 1.00 & & & & \\
\hline & P4 & $0.80^{*}$ & $0.96^{*}$ & -0.10 & 1.00 & & & \\
\hline & P5 & 0.75 & $0.84 *$ & -0.10 & $0.95^{*}$ & 1.00 & & \\
\hline & P6 & 0.73 & $0.81^{*}$ & -0.20 & $0.91^{*}$ & $0.97 *$ & 1.00 & \\
\hline \multirow{6}{*}{ 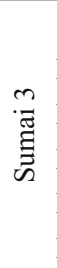 } & & P1 & $\mathrm{P} 2$ & P3 & $\mathrm{P} 4$ & P5 & & \\
\hline & $\mathrm{P} 1$ & 1.00 & & & & & & \\
\hline & $\mathrm{P} 2$ & $0.87^{*}$ & 1.00 & & & & & \\
\hline & P3 & 0.69 & 0.28 & 1.00 & & & & \\
\hline & P4 & $0.89^{*}$ & 0.64 & $0.91 *$ & 1.00 & & & \\
\hline & P5 & $0.90 *$ & 0.58 & $0.93 *$ & $0.97 *$ & 1.00 & & \\
\hline
\end{tabular}

of aggressiveness according to a previous characterization (Ortega 2017; Ortega et al. 2018) (Table 2). At anthesis, wheat spikes were independently inoculated with a suspension of $3 \times 10^{5}$ conidia $/ \mathrm{mL}$ of each isolate by means of a hand sprayer (Alberione et al. 2016). Nine treatments were obtained from the combination of each cultivar with an isolate. The control plants were inoculated with distilled water. The experimental design was randomized complete blocks and the experimental units were hill plots. The assay was done by quadruplicate.

\section{Infection parameters: severity and yield}

After harvest, the degree of infection was estimated calculating the percentage of infected spikelets by spike, which is related to infection severity, and the thousand kernel weight (TKW) related to yield (Alberione et al. 2016).
Table 4 Infection effect on chromatogram peak areas by RP-HPLC according to Pearson's correlation values between disease degree parameters and ANOVA for the isolate effect

\begin{tabular}{|c|c|c|c|c|}
\hline \multirow[t]{2}{*}{ Wheat cultivar } & \multirow[t]{2}{*}{ Peak } & \multicolumn{2}{|c|}{ Pearson's correlation } & \multirow[t]{2}{*}{$\operatorname{ANOVA}(p)$} \\
\hline & & Severity & TKW & \\
\hline \multirow[t]{7}{*}{ Sy 200} & $\mathrm{P} 1$ & -0.44 & 0.56 & 0.152 \\
\hline & $\mathrm{P} 2$ & -0.47 & 0.60 & $0.042 *$ \\
\hline & P3 & -0.50 & 0.68 & 0.079 \\
\hline & $\mathrm{P} 4$ & -0.49 & 0.65 & $0.030^{*}$ \\
\hline & P5 & -0.51 & 0.63 & 0.294 \\
\hline & P6 & -0.50 & 0.66 & $0.033 *$ \\
\hline & P7 & -0.55 & 0.35 & $0.029^{*}$ \\
\hline \multirow[t]{5}{*}{ AGP Fast } & $\mathrm{P} 1$ & $-0.82 *$ & 0.66 & 0.147 \\
\hline & $\mathrm{P} 2$ & $-0.86^{*}$ & 0.69 & 0.103 \\
\hline & P3 & $-0.88 *$ & 0.78 & 0.111 \\
\hline & $\mathrm{P} 4$ & $-0.91 *$ & 0.76 & $0.049^{*}$ \\
\hline & P5 & $-0.99 *$ & $0.88 *$ & $0.009^{*}$ \\
\hline \multirow[t]{6}{*}{ Klein Tigre } & $\mathrm{P} 1$ & 0.18 & -0.13 & 0.172 \\
\hline & $\mathrm{P} 2$ & -0.52 & 0.37 & $0.004 *$ \\
\hline & $\mathrm{P} 3$ & $-0.82 *$ & $0.99 *$ & 0.748 \\
\hline & $\mathrm{P} 4$ & -0.49 & 0.50 & $0.005^{*}$ \\
\hline & P5 & -0.46 & 0.59 & $0.034 *$ \\
\hline & P6 & -0.58 & 0.70 & $0.048^{*}$ \\
\hline \multirow[t]{5}{*}{ Sumai 3} & $\mathrm{P} 1$ & $-0.95^{*}$ & $0.88 *$ & - \\
\hline & $\mathrm{P} 2$ & -0.70 & 0.56 & - \\
\hline & $\mathrm{P} 3$ & $-0.85^{*}$ & $0.95 *$ & - \\
\hline & $\mathrm{P} 4$ & $-0.95^{*}$ & $0.98 *$ & - \\
\hline & P5 & $-0.98^{*}$ & $0.99 *$ & - \\
\hline
\end{tabular}

$T K W$, thousand kernels weight; $* p<0.05$. Sumai 3 was tested against isolate 2 of medium severity

\section{High-molecular-weight glutenin subunit analysis}

\section{Protein extraction}

After grain severity and yield measurements, the whole wheat flours were obtained by milling the grains with an electric grinder FW 100 (Arcano, Argentina). The protein extraction was carried out according to Naeem and Sapirstein (2007). Fifty milligrams of flour from each sample was used for the extractions. The gliadin fraction was extracted by three consecutive washes of the flours with $500 \mu \mathrm{L}$ of 1-propanol $(0.5 \mathrm{~mL} / \mathrm{mL})$ solution, for $15 \mathrm{~min}$ at room temperature, and it was centrifuged for $3 \mathrm{~min}$ at $15000 \times g$. The supernatant was discarded. The glutenins contained in the pellet were extracted with $150 \mu \mathrm{L}$ of buffer (0.08 M Tris- $\mathrm{HCl}, 0.5 \mathrm{~mL} / \mathrm{mL} 1$-propanol, $\mathrm{pH}$ 7.5) with $10 \mathrm{mg} / \mathrm{mL}$ dithiothreitol (DTT). The mix was incubated for $30 \mathrm{~min}$ at $60{ }^{\circ} \mathrm{C}$ and then $150 \mu \mathrm{L}$ of the extraction buffer 

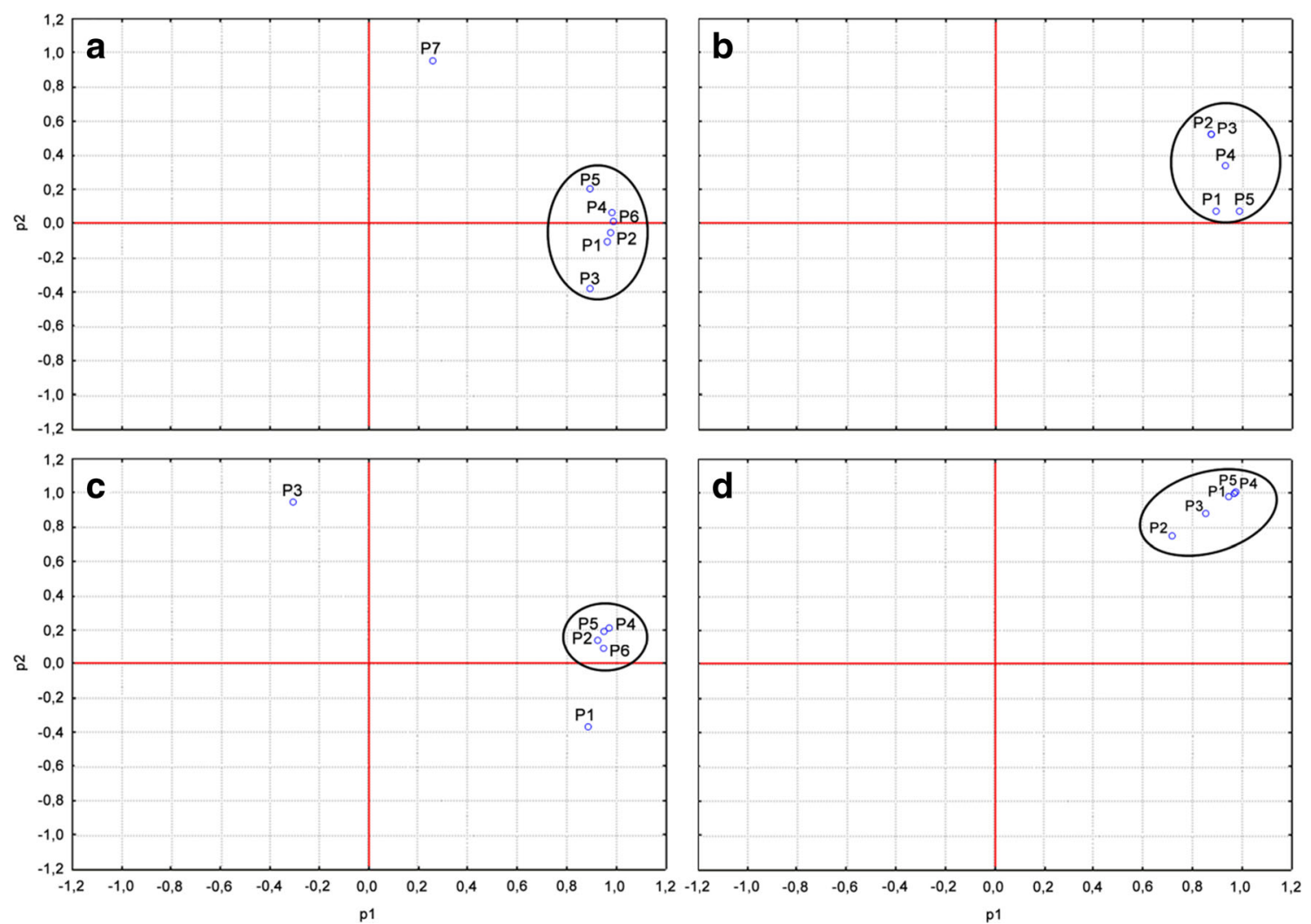

Fig. 3 PCA score plot of the areas calculated under the protein peaks on RP-HPLC chromatography. Cultivars: Sy 200 (a), AGP Fast (b), Klein Tigre (c), Sumai 3 (d). P1-P7, protein peaks

with $40 \mu \mathrm{L} / \mathrm{mL} 4$-vinylpyridine was added and incubated for $30 \mathrm{~min}$ at $60{ }^{\circ} \mathrm{C}$. The mix was centrifuged and fractioned. Lastly, the samples were analyzed by highperformance liquid chromatography by reversed phase (RP-HPLC). For the electrophoretic analysis, the samples were lyophilized and stored at $-4{ }^{\circ} \mathrm{C}$ until posterior use.

\section{Chromatographic analysis}

The analysis of the samples by RP-HPLC was carried out according to Naeem and Sapirstein (2007) with modifications. The employed equipment was a Waters 717 with reversed-phase column Aquapore RP-300 7m (300- $\mu \mathrm{m}$ pore size, $7-\mu \mathrm{m}$ particle size). The employed solvents were the following: solvent $\mathrm{A}-80 \mu \mathrm{L}$ of trifluoroacetic acid (TFA) in $1 \mathrm{~L}$ of bidistilled water; solvent $\mathrm{B}-80 \mu \mathrm{L}$ of TFA, $440 \mathrm{~mL}$ acetonitrile, $560 \mathrm{~mL}$ bidistilled water. The gradient was the following ( $\%$ of solvent B): $0-7 \min 52 \%$ B; 7-54 min $100 \%$ B; $54-55 \min 52 \%$ B; $55-65 \min 52 \%$ B. The injection volume was $20 \mu \mathrm{L}$ and the flow was $1 \mathrm{~mL} / \mathrm{min}$. The detection was carried out with diode array equipment (Waters, MA, USA) at $206 \mathrm{~nm}$. In the chromatograms, the area under peaks was integrated as an estimate of the protein content employing Empower software (Waters, MA, USA).

\section{Electrophoretic analysis}

Electrophoresis was carried out on mini-PROTEAN Tetra cell (Bio-Rad, CA, USA) equipment, on $8 \%$ polyacrylamide gel employing 10-180-kDa Page Ruler molecular marker (Thermo Fisher, MA, USA). The dried samples previously obtained were resuspended in $300 \mu \mathrm{L}$ of sample buffer $(40 \mathrm{mg} / \mathrm{mL}$ SDS, $120 \mu \mathrm{L} / \mathrm{mL}$ glycerol, $6.1 \mathrm{mg} /$ $\mathrm{mL}$ Tris- $\mathrm{HCl}, 50 \mu \mathrm{L} / \mathrm{mL} \beta$-mercaptoethanol, $10 \mathrm{mg} / \mathrm{mL}$ DTT and $0.1 \mathrm{mg} / \mathrm{mL}$ Coomassie Brilliant Blue R 250, $\mathrm{pH}$ 6.8), sonicated for $30 \mathrm{~min}$ and then incubated for 5 min at $90{ }^{\circ} \mathrm{C}$ according to Eggert et al. (2011). The pictures were taken with Quantity One software (BioRad, CA, USA) and analyzed with the software Gel Analyzer 2010 (Freeware). The density values obtained from the densitograms were employed as an estimate of the protein content of the band. The identification of the different electrophoretic profiles obtained from HMW-GS glutenins was performed according to Payne et al. (1987).

\section{Statistical analysis}

The data was analyzed employing STATISTICA 7 (StatSoft, OK, USA). The relations between variables were 


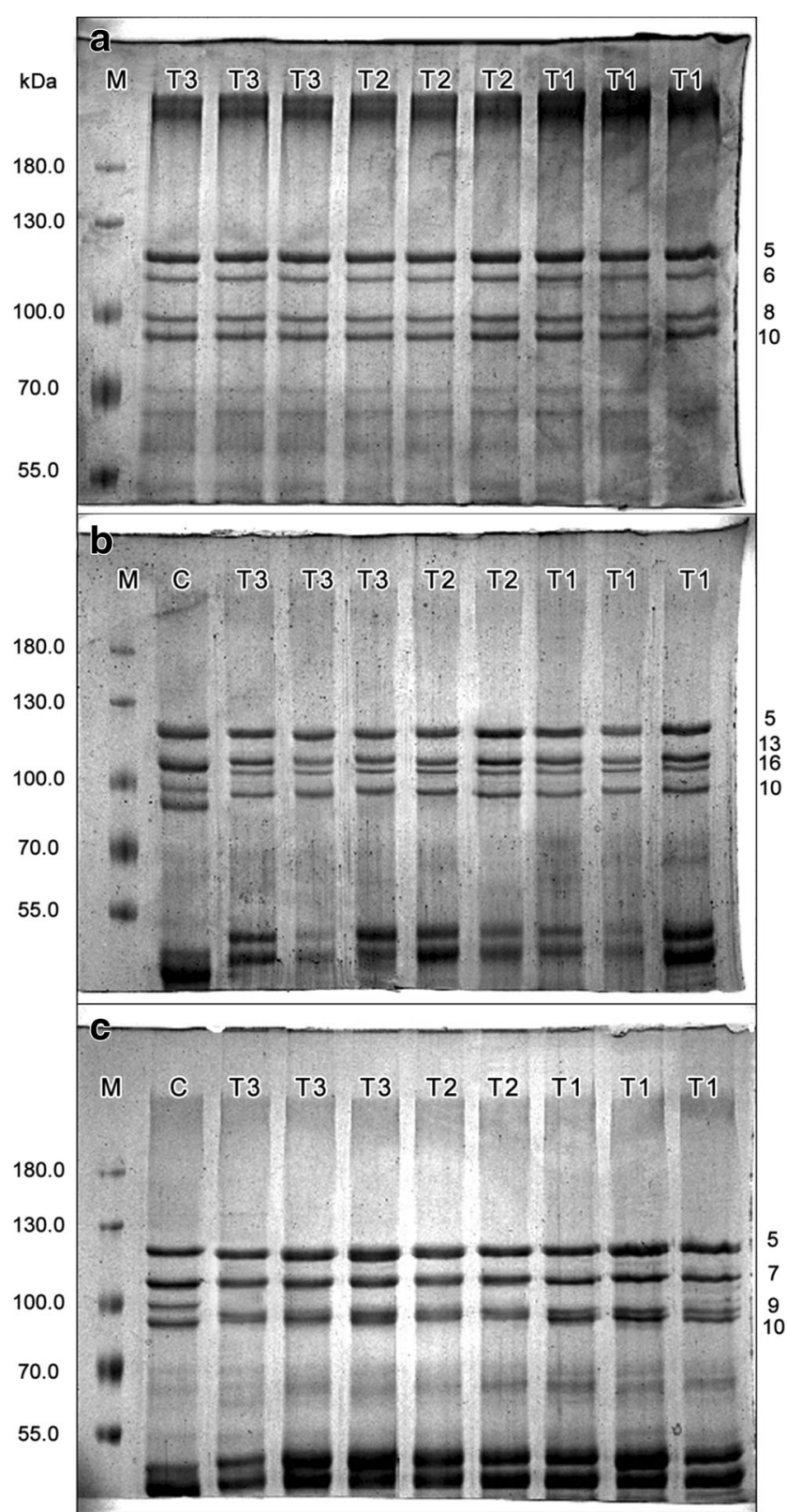

Fig. 4 SDS-PAGE of glutenin extracts obtained from Sy 200 (a), AGPFast (b), and Klein Tigre (c) cultivars. M, molecular marker (55$180 \mathrm{kDa}$ ). C, Sumai 3 control cultivar. T1-T3, isolates employed for inoculation. The numeration from the right is the HMW-GS protein profiles assigned according to Payne et al. (1987)

analyzed by Pearson's correlations, the isolate effect on the severity degree was analyzed by variance analysis (ANOVA), and how proteins clustered was observed by principal component analysis (PCA).

\section{Results and discussion}

The artificial infection of wheat plants employing isolates with different aggressiveness allowed us to observe a wide range of
Table 5 Pearson's correlation matrix of bands densitograms from SDSPAGE for wheat cultivars

\begin{tabular}{|c|c|c|c|c|c|}
\hline \multirow{5}{*}{$\begin{array}{l}\stackrel{8}{8} \\
\text { त } \\
\text { क }\end{array}$} & Band & 5 & 6 & 8 & 10 \\
\hline & 5 & 1.00 & & & \\
\hline & 6 & $0.98^{*}$ & 1.00 & & \\
\hline & 8 & $0.94 *$ & $0.94 *$ & 1.00 & \\
\hline & 10 & $0.89^{*}$ & $0.91^{*}$ & $0.97^{*}$ & 1.00 \\
\hline \multirow{5}{*}{ 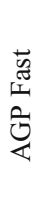 } & & 5 & 13 & 16 & 10 \\
\hline & 5 & 1.00 & & & \\
\hline & 13 & 0.76 & 1.00 & & \\
\hline & 16 & 0.75 & 0.70 & 1.00 & \\
\hline & 10 & 0.66 & 0.24 & 0.78 & 1.00 \\
\hline \multirow{5}{*}{ 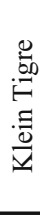 } & & 5 & 7 & 9 & 10 \\
\hline & 5 & 1.00 & & & \\
\hline & 7 & 0.63 & 1.00 & & \\
\hline & 9 & 0.64 & 0.41 & 1.00 & \\
\hline & 10 & -0.01 & -0.40 & 0.47 & 1.00 \\
\hline \multirow{5}{*}{ 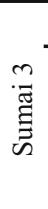 } & & 2 & 7 & 8 & 12 \\
\hline & 2 & 1.00 & & & \\
\hline & 7 & $0.88^{*}$ & 1.00 & & \\
\hline & 8 & $0.93 *$ & 0.82 & 1.00 & \\
\hline & 12 & $0.97 *$ & $0.96^{*}$ & $0.95^{*}$ & 1.00 \\
\hline
\end{tabular}

$* p<0.05$

disease severity in relation to the changes detected in the HMW-GS protein fraction by analytical techniques. These proteins are responsible for important baking characteristics in the industry (Belton 2005; D'Ovidio and Masci 2004; Kamal et al. 2009).

The effect of the disease on the 9 treatments of field-grown wheat under controlled conditions was measured as the percentage of severity and TKW. As shown in Fig. 1, a diverse degree of infection was obtained from the wheat plants infected with $F$. graminearum isolates of different aggressiveness. Furthermore, it was observed that the isolate 1 produced the lowest disease effects, which was in agreement with its characterization of aggressiveness.

The RP-HPLC studies were carried out from the protein extracts obtained of whole wheat flour for each treatment. Representative protein elution profiles of wheat cultivars Sy 200, AGP Fast, and Klein Tigre and the control Sumai 3 infected with isolate 2 are shown in Fig. 2.

The regions corresponding to HMW-GS and LMW-GS fractions were identified by the retention time according to previous researches (Eggert et al. 2010; Naeem and Sapirstein 2007). As an estimate of protein content, the areas under the peaks were employed. Table 3 shows the correlation between values of protein peak integrations for each cultivar. It can be observed, for the cultivars Sy 200 and AGP Fast, that most of the peaks correlated positively with each other, whereas for cultivar Klein Tigre, peaks showed some negative 
Table 6 Infection effect on band densitograms from SDS-PAGE according to Pearson's correlation values between disease degree parameters and ANOVA for the isolates effect

\begin{tabular}{|c|c|c|c|c|}
\hline \multirow[t]{2}{*}{ Wheat cultivar } & \multirow[t]{2}{*}{ Band no. } & \multicolumn{2}{|c|}{ Pearson's correlation } & \multirow[t]{2}{*}{$\operatorname{ANOVA}(p)$} \\
\hline & & Severity & TKW & \\
\hline \multirow[t]{4}{*}{ Sy 200} & 5 & $-0.84 *$ & $0.91 *$ & 0.17 \\
\hline & 6 & $-0.78^{*}$ & $0.83^{*}$ & 0.213 \\
\hline & 8 & -0.77 & 0.78 & 0.317 \\
\hline & 10 & $-0.80 *$ & 0.74 & 0.424 \\
\hline \multirow[t]{4}{*}{ AGP Fast } & 5 & -0.24 & 0.48 & $0.016^{*}$ \\
\hline & 13 & -0.65 & 0.77 & $0.049 *$ \\
\hline & 16 & -0.73 & $0.82 *$ & $0.046^{*}$ \\
\hline & 10 & 0.00 & -0.04 & 0.248 \\
\hline \multirow[t]{4}{*}{ Klein Tigre } & 5 & -0.28 & -0.03 & $0.042^{*}$ \\
\hline & 7 & -0.38 & 0.3 & 0.643 \\
\hline & 9 & -0.02 & 0.28 & $0.029^{*}$ \\
\hline & 10 & -0.13 & -0.04 & 0.568 \\
\hline \multirow[t]{4}{*}{ Sumai 3} & 2 & -0.81 & $0.93 *$ & - \\
\hline & 7 & $-0.95^{*}$ & $0.96^{*}$ & - \\
\hline & 8 & $-0.86^{*}$ & $0.95^{*}$ & - \\
\hline & 12 & $-0.93^{*}$ & $0.99 *$ & - \\
\hline
\end{tabular}

$T K W$, thousand kernels weight; $* p<0.05$. Sumai 3 was tested against isolate 2 of medium severity

correlations. The positive correlations suggest that protein changes resulting from infection were similar within each analyzed protein group.

In order to analyze the effect of the disease, Pearson's correlation between the values of proteic profile obtained by HPLC and disease severity and TKW—representing the degree of infection-was calculated (Table 4).

Almost all correlations between protein content and severity were negative, indicating that the higher the severity, the lower the protein signals. For the yield-measured as $\mathrm{TKW}$ - the correlations were positive, but less significant. These results were in concordance with the observations of Wang et al. (2005), who reported that higher levels of infection with Fusarium culmorum reduced the glutenin percentage - especially HMW-GS; meanwhile, Nightingale et al. 1999 found less amount of proteins in Fusarium damaged kernels compared to clean grains. Eggert et al. (2010) compared the effect of natural and artificial infection and found that the latter induced lower protein values.

The isolate effect on the protein values was also analyzed by ANOVA, finding significant differences among them. Isolate 1 was found to have the lowest degree of infection as it produced the lowest protein changes (Table 4).

From the protein data analyzed by PCA for each cultivar, two principal components were obtained, which explained $80.85 \%, 88.48 \%$, and $93.33 \%$ of the total variance (cultivars
Sy200, AGP Fast, and Klein Tigre respectively). The representation of the principal components is shown in Fig. 3, in which the peaks were grouped for all cultivars, except for those that present lower Pearson's correlations values.

Lastly, the protein extracts obtained from the flours were analyzed by SDS-PAGE. A representative gel of each analyzed wheat cultivar is shown in Fig. 4.

The density values obtained from the densitograms were employed as an estimate of the band protein content, which lead to the positive correlation with the infection degree. The analysis of Pearson's correlations of the protein bands showed that almost all band values were positively correlated, showing similitude with the results observed by RP-HPLC (Table 5).

Pearson's correlations between the values obtained by SDS-PAGE and severity and TKW were calculated in order to analyze the effect of the disease. These results are shown in Table 6. Negative correlations between protein band values and severity were found for all cultivars, indicating that at a higher severity, a lower signal of proteins was found. In relation to yield, almost all correlations were positive. Similar results were previously observed, where negative effects on HMW-GS by Fusarium infection were reported (Eggert et al. 2010; Horvat et al. 2014; Kreuzberger et al. 2015; Wang et al. 2005).

In conclusion, negative correlations between the protein profile and the disease severity could be observed employing both techniques. This would indicate that the protein fraction is sensitive to alterations caused by the disease. Although the SDS-PAGE methodology is a reference technique for the identification of the HMW-GS profile, the HPLC proved to be a complementary, powerful, and rapid method for the analysis of the severity degree effect in the protein fraction given its resolution and sensibility. To our knowledge, the approaches employed for the analysis of protein changes according to the degree of disease, as well as the thorough statistical analysis, are novel for the analysis of FHB and its implications in the quality of flours.

Funding information We thank Consejo Nacional de Investigaciones Científicas y Tecnológica (Grant PIP 0819) for the financial support.

Compliance with ethical standards This article does not contain any studies with human participants or animals performed by any of the authors.

Publisher's Note Springer Nature remains neutral with regard to jurisdictional claims in published maps and institutional affiliations.

\section{References}

Akinsanmi OA, Backhouse DA, Simpfendorfer SR, Chakraborty S (2008) Mycelial compatibility reactions of Australian Fusarium 
graminearum and F. pseudograminearum isolates compared with AFLP groupings. Plant Pathol 57:251-261

Alberione EJ, Ortega LM, Salines N, Astoreca AL, Alconada TM (2016) Genetic behavior of different wheat genotypes against Fusarium graminearum. Agrociencia 250:335-346

Alvarez CL, Somma S, Proctor RH, Stea G, Mulè G, Logrieco AFR, Fernández Pinto VE, Moretti A (2011) Genetic diversity in Fusarium graminearum from a major wheat-producing region of Argentina. Toxins 3:1294-1309

Barneix AJ (2007) Physiology and biochemistry of source-regulated protein accumulation in the wheat grain. J Plant Physiol 164:581-590

Belton PS (2005) New approaches to study the molecular basis of the mechanical properties of gluten. J Cereal Sci 41:203-211

Brzozowski B, Dawidziuk K, Bednarski W (2008) Gliadin degradation by proteases of Fusarium genus fungi in different in vivo and in vitro conditions. Pol J Nat Sci 23:188-206

Castañares E, Albuquerque DR, Dinolfo MI, Fernández Pinto VE, Patriarca A, Stenglein SA (2014) Trichothecene genotypes and production profiles of Fusarium graminearum isolates obtained from barley cultivated in Argentina. Int J Food Microbiol 179:57-63

D'Ovidio R, Masci S (2004) The low-molecular-weight glutenin subunits of wheat gluten. J Cereal Sci 39:321-339

DuPont FM, Altenbach SB (2003) Molecular and biochemical impacts of environmental factors on wheat grain development and protein synthesis. J Cereal Sci 38:133-146

Eggert K, Wieser H, Pawelzik E (2010) The influence of Fusarium infection and growing location on the quantitative protein composition of (part I) emmer (Triticum dicoccum). Eur Food Res Technol 230:837-847

Eggert K, Rawel HM, Pawelzik E (2011) In vitro degradation of wheat gluten fractions by Fusarium graminearum proteases. Eur Food Res Technol 233:697-705

FAO (2015). Worldwide regulations for mycotoxins in food and feed http:// www.fao.org/publications/soco/2015/es/ Accessed 3 August 2017

Gianibelli MC, Larroque OR, MacRitchie F, Wrigley CW (2001) Biochemical, genetic, and molecular characterization of wheat glutenin and its component subunits. Cereal Chem 78:635-646

Gras PW, Anderssen RS, Keentok M, Békés F, Appels R (2001) Gluten protein functionality in wheat flour processing: a review. Aust J Agric Res 52:1311-1323

Horvat DI, Spanic V, Dvojkovic K, Simic GH, Magdic DN, Nevistic A (2014) The influence of Fusarium infection on wheat (Triticum aestivum L.) proteins distribution and baking quality. Cereal Res Commun 43:61-71

Kamal AHM, Kim KH, Shin KH, Seo HS, Tsujimoto H, Heo HY, Choi JS, Park CS, Woo SH (2009) Diversity of novel glutenin subunits in bread wheat (Triticum aestivum L.). J Plant Biol 52:533-542

Kang Z, Buchenauer H (2000) Ultrastructural and cytochemical studies on cellulose, xylan and pectin degradation in wheat spikes infected by Fusarium culmorum. J Phytopathol 148:263-275

Kang Z, Zingen-Sell I, Buchenauer H (2005) Infection of wheat spikes by Fusarium avenaceum and alterations of cell wall components in the infected tissue. Eur J Plant Pathol 111:19-28

Kikot GE, Hours RA, Alconada TM (2009) Contribution of cell wall degrading enzymes to pathogenesis of Fusarium graminearum: a review. J Basic Microbiol 49:231-241

Kikot GE, Moschini RC, Consolo VF, Rojo RA, Salerno GL, Hours RA, Gasoni LA, Arambarri AM, Alconada Magliano TM (2011) Occurrence of different species of Fusarium from wheat in relation to disease levels predicted by a weather-based model in Argentina Pampas region. Mycopathologia 117:139-149

Kreuzberger M, Limsuwan S, Eggert K, Karlovsky P, Pawelzik E (2015) Impact of Fusarium spp. infection of bread wheat (Triticum aestivum $\mathrm{L}$.) on composition and quality of flour in association with EU maximum level for deoxynivalenol. J Appl Bot Food Qual 88: $177-185$
Larroque OR, Gianibelli MC, Gomez Sanchez M, MacRitchie F (2000) Procedure for obtaining stable protein extracts of cereal flour and whole meal for size-exclusion HPLC analysis. Cereal Chem 77: $448-450$

Malbrán I, Mourelos CA, Girotti JR, Aulicino MB, Balatti PA, Lori GA (2012) Aggressiveness variation of Fusarium graminearum isolates from Argentina following point inoculation of field grown wheat spikes. Crop Prot 42:234-243

McMullen MP, Jones RK, Gallemberg D (1997) Scab of wheat and barley: a re-emerging disease of devastating impact. Plant Dis 81:1340-1348

Mesterházy Á, Bartók T, Mirocha CG, Komoróczy R (1999) Nature of wheat resistance to Fusarium head blight and the role of deoxynivalenol for breeding. Plant Breed 118:97-110

Monds RD, Cromey MG, Lauren DR, di Menna M, Marshall J (2005) Fusarium graminearum, $F$. cortaderieae and $F$. pseudograminearum in New Zealand: molecular phylogenetic analysis,mycotoxin chemotypes and coexistence of species. Mycol Res 109:410-420

Naeem HA, Sapirstein HD (2007) Ultra-fast separation of wheat glutenin subunits by reversed-phase HPLC using a superficially porous silica-based column. J Cereal Sci 46:157-168

Nightingale MJ, Marchylo BA, Clear RM, Dexter JE, Preston KR (1999) Fusarium head blight: effect of fungal proteases on wheat storage proteins. Cereal Chem 76(1):150-158

Ortega LM (2017) Caracterización de aislamientos de Fusarium graminearum y su relación con el deterioro de granos de trigo infectados. National University of La Plata Argentina, Doctoral dissertation

Ortega LM, Dinolfo MI, Astoreca AL, Alberione EJ, Stenglein SA, Alconada TM (2016) Molecular and mycotoxin characterization of Fusarium graminearum isolates obtained from wheat at a single field in Argentina. Mycol Prog 15(1):1-8

Ortega LM, Moure MC, Astoreca AL, Alberione EJ, Alconada TM (2018) Wheat grains damaged by Fusarium graminearum: alterations in yield, toxicity and protein composition. Vegetos 31:2

Palacios SA, Ramírez ML, Cabrera Zalazar M, Farnochi MC, Zappacosta D, Chiacchiera SM, Reynoso MM, Chulze SN, Torres AM (2011) Occurrence of Fusarium spp. and fumonisin in durum wheat grains. J Agric Food Chem 59:12264-12,269

Payne PI, Nightingale MA, Krattiger AF, Holt LM (1987) The relationship between HMW glutenin subunit composition and the breadmaking quality of British-grown wheat varieties. J Sci Food Agric 40:51-65

Pritsch C, Muehlbauer GJ, Bushnell WR, Somers DA, Vance CP (2000) Fungal development and induction of defense response genes during early infection of wheat spikes by Fusarium graminearum. Mol Plant-Microbe Interact 13:159-169

Shewry PR, Hawkesford MJ, Piironen V, Lampi AM, Gebruers K, Boros D, Andersson AAM, Aman P, Rakszegi M, Bedo Z, Ward JL (2013) Natural variation in grain composition of wheat and related cereals. J Agric Food Chem 61:8295-8303

Tóth B, Mesterházy Á, Horváth Z, Bartók T, Varga M, Varga J (2005) Genetic variability of central European isolates of the Fusarium graminearum species complex. Eur J Plant Pathol 113:35-45

Ueno T, Stevenson SG, Preston KR, Nightingale MJ, Marchylo BM (2002) Simplified dilute acetic acid based extraction procedure for fractionation and analysis of wheat flour protein by size exclusion HPLC and flow field-flow fractionation. Cereal Chem 79:155-161

Wang J, Wieser H, Pawelzik E, Weinert J, Keutgen AJ, Wolf GA (2005) Impact of the fungal protease produced by Fusarium culmorum on the protein quality and breadmaking properties of winter wheat. Eur Food Res Technol 220:552-559

Wanjiru WM, Zhensheng K, Buchenauer H (2002) Importance of cell wall degrading enzymes produced by Fusarium graminearum during infection of wheat heads. Eur J Plant Pathol 108:803-810

Wieser H (2007) Chemistry of gluten proteins. Food Microbiol 24:115-119 